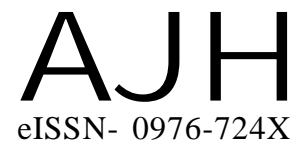

Received : 13.09.2016

Revised : 17.11.2016

Accepted : 27.11.2016

Members of the Research Forum

Associated Authors:

${ }^{1}$ Department of Horticulture, Faculty

of Agriculture, Annamalai

University, Annamalai Nagar,

CHIDAMBARAM (T.N.) INDIA

Author for correspondence :

E. ARIVAZHAGAN

Department of Horticulture, Faculty

of Agriculture, Annamalai

University, Annamalai nagar,

CHIDAMBARAM (T.N.) INDIA
THEASIAN JOURNALOF HORTICULTURE

Volume 11 | Issue 2 | December, 2016 | 393-395

Visit us -www.researchjournal.co.in

RESEARCH PAPER

DOI : 10.15740/HAS/TAJH/11.2/393-395

\title{
Evaluation of sapota cultivars for growth characters
}

\section{N. RAMADOSS ${ }^{1}$ AND E. ARIVAZHAGAN}

ABSTRACT : An investigation was carried out at the Department of Horticulture, Faculty of Agriculture, Annamalai University during 2014-2015 to evaluate the performance of eight sapota cultivars, viz., PKM 1, Virudhunagar, Kirthibarthi Round, Cricket Ball, CO 2, Pala, Oval and Kirthibarthi Oval was studied in two seasons viz., February to April (peak season I) and July to September (peak season II). The experiment was laid out in Randomized Block Design (RBD) in three replications. The per se performance of the cultivar Cricket ball excelled the other cultivars upon evaluating for growth characters like tree height, tree circumference, shoot length, shoot girth, number of leaves per shoot, leaf length and leaf breadth followed by $\mathrm{CO} 2$ and Virudhunagar.

KEY WORDS : Sapota, Growth, Morphology

HOW TO CITE THIS ARTICLE : Ramadoss, N. and Arivazhagan, E. (2016). Evaluation of sapota cultivars for growth characters. Asian J. Hort., 11(2) : 393-395, DOI : 10.15740/HAS/TAJH/11.2/393395. 